\title{
TEACHER PERSPECTIVES ON HIGH SCHOOL IN ACEH PROVINCE ABOUT NATURAL DISASTERS
}

\author{
Rina Fitri' ${ }^{1}$, Sulastri², Ismail AB ${ }^{1}$ \\ 1Program Studi Magister Ilmu Kebencanaan, Universitas Syiah Kuala \\ Jl. Hamzah Fansuri No. 3, Darussalam, Banda Aceh, 23111, Indonesia \\ 2Pendidikan Kimia, Fakultas Keguruan dan Ilmu Pendidikan, Universitas Syiah Kuala \\ Jl. Teuku Nyak Arief, Darussalam, banda Aceh, 23111, Indonesia \\ e-mail: rina.fitrirafi@gmail.com
}

Received: 15 March 2021, Repaired: 04 July 2021, Approved: 06 July 2021

\begin{abstract}
Abstrak
Pemerintah Indonesia telah berupaya untuk pemulihan struktur dan pengembangan respon sekolah, mencakup peningkatan pengetahuan, keterampilan, sistem operasi penanggulangan bencana di sekolah. Pimpinan Sekolah dan guru diharapkan untuk menyeimbangkan kebutuhan akan prosedur operasi standar dengan kemampuan struktur organisasi dalam menanggapi masalah khusus yang disebabkan oleh bencana. Peningkatan Guru diharapkan dapat memberikan peranan lebih aktif bagi siswa sekaligus mengatasi stress mereka sendiri dalam situasi pascabencana. Tujuan penelitian ini adalah mengkaji perspektif guru SMA tentang pengetahuan bencana alam dan mitigasi bencana alam. Pendekatan statistika deskriptif dilakukan untuk menggambarkan, menjelaskan perspektif pengetahuan guru dan mitigasi terhadap bencana alam. Menjelaskan seberapa besar pengaruh atau hubungan antara pengetahuan yang dimiliki guru terhadap mitigasi bencana, dilakukan dengan menggunakan analisis regresi linier. Sampel pada penelitian ini merupakan guru SMA di provinsi Aceh dengan jumlah sebanyak 389 guru. Pengumpulan data penelitian menggunakan instrumen berupa kuisioner. Hasil penelitian menunjukkan perspektif guru SMA mengenai pengetahuan bencana alam rata-rata berkategori tinggi, rata-rata guru mengetahui pengetahuan umum bencana alam, tandatanda bencana, klasifikasi bencana alam dan penyebab bencana alam. Tidak jauh berbeda dengan hasil perspektif guru mengenai mitigasi bencana alam berkategori sangat tinggi, perencanaan dalam proses mitigasi, kebijakan, prosedur operasional kebencanaan, tandatanda evakuasi bencana telah diketahui oleh guru SMA di provinsi Aceh. Tingkat pengetahuan guru SMA dengan mitigasi memiliki hubungan yang signifikan, sehingga semakin tingginya pengetahuan guru SMA tentang pengetahuan bencana alam, maka akan semakin meningkatkan kemampuan mitigasi guru SMA menghadapi bencana alam
\end{abstract}

Kata kunci: Perspektif Guru, Pengetahuan Bencana Alam, Mitigasi Bencana Alam, Analisis Regresi

\begin{abstract}
The Indonesian government has made efforts to restore the structure and development of school responses, including increasing knowledge, skills, and disaster management operating systems in schools. School leaders and teachers are expected to balance the need for standard operating procedures with the ability of organizational structures to respond to specific problems caused by disasters. Teacher enhancement is expected to provide a more active role for students and overcome their stress in post-disaster situations. This study aimed to examine the perspective of high school teachers on knowledge of natural disasters and natural disaster mitigation. A descriptive statistical approach is used to describe and explain teacher knowledge and mitigate natural disasters. Explaining how much influence or relationship between teachers' knowledge on disaster mitigation is done. The sample in this study was high school teachers in Aceh province, with 389 teachers. The research data
\end{abstract}


collection used an instrument in the form of a questionnaire. The results showed that the perspective of high school teachers regarding knowledge of natural disasters was in the high category on average; the average teacher knew general knowledge of natural disasters, signs of catastrophe, classification of natural disasters, and causes of natural disasters. Not much different from the results of the teacher's perspective regarding natural disaster mitigation in the very high category, planning in the mitigation process, policies, operational disaster procedures, signs of disaster evacuation have been recognized by SMA teachers in Aceh province. The level of knowledge of high school teachers with mitigation has a significant relationship, so the higher the knowledge of high school teachers about natural disasters, the more high-school teachers can mitigate against natural disasters.

Keywords: Teacher's Perspective, Natural Disaster Knowledge, Natural Disaster Mitigation, Regression Analysis

\section{INTRODUCTION}

Natural disasters are a phenomenon that occurs a result of the combination of hazard components affecting biological and environmental conditions (Oxfam, 2012). According to Law Number 24 of 2007, natural disasters are disasters caused by events or series of events caused by nature such as earthquakes, volcanic eruptions, floods, droughts, hurricanes, landslides, and tsunamis. According to Damanik \& Restu (2012) natural disasters cause huge losses to the community due to the lack of information obtained by the community regarding the possibility of a disaster. Natural disaster management and the implementation of disaster management are the government's responsibility because the function of the state must provide protection and welfare for its citizens (Arif \& Rosni, 2011).

The earthquake and tsunami disaster in Aceh in 2004 became a warning for Indonesia to understand the significance of how dangerous the tragedy is in all aspects. It takes readiness, both in the formation of institutional institutionalization, policy and program work, and budgeting for disaster mitigation, emergency to rehabilitation, and post-disaster reconciliation. The earthquake and tsunami disaster cannot be prevented suddenly and cannot predict precisely and accurately its strength, time of occurrence, and central location. Therefore, efforts are needed to increase preparedness by the government, the community, and individuals in responding to impacts or hazards that may occur (Sari et al., 2019). Nurmayani (2018) stated that preparedness minimizes the adverse effects through effective preventive measures when natural disasters occur.

The school-based disaster Program focuses on developing the structure, infrastructure, and school system. Structures and infrastructures include school development, while the school system includes improved knowledge, skills, modules, school early warning systems, school emergency planning, and the capacity of school resource mobilization during disasters (LIPI and UNESCO, 2010). Changes in the school curriculum have changed from time to time. School hours are currently increasing on average, where students and teachers come home late in the evening, including in Aceh. This is one factor that must be considered because teachers and students spend more time in school, and disasters can come at any time without knowing the time and place. However, reality, schools in Aceh Province, incredibly high school level, do not yet have SOP on natural disaster mitigation which is very important for disaster management. Schools have an essential role in creating a wider community, especially school communities, where teachers and students are aware of disasters. Wedyawati (2017) stated that a disaster response attitude is needed when dealing with natural disasters. Disaster risk reduction can be integrated into the subject matter in schools. 
Research conducted by (Nakano et al., 2019) stated that students are more interested in acquiring knowledge of natural disasters related to protecting themselves. The school context causes this motivational tendency: schools teach decontextual knowledge even though it is necessary to contextualize disaster education in everyday life. This study argues that the effectiveness of disaster education is by the context in which students learn and the finding that educational practice should be designed based on the context of the learners.

Based on the research conducted by Adiyoso (2013) regarding the effectiveness of the impact of the implementation of disaster education in the school against the preparedness of students facing the tsunami in Aceh stated that performance of a curriculum-based disaster issue in schools could arouse school children's preparedness even though it is limited only to visits to education facilities and emergency facilities. Schools that implement disaster-based curriculum issues are more effective in improving disaster knowledge, increasing the level of risk perception, the preparedness of individuals and schools (Adiyoso and Kanegae, 2013). According to Karyono (2010), The Ministry of National Education implemented disaster regulations in 2011, from elementary to high school education. Disaster education has the general purpose of providing an overview and reference in the disaster process. However, in practice it is not included directly into a special disaster subject or curriculum; it is factually incorporated into the subject in understanding and anticipating natural conditions in an integrated manner.

A ten-year-old British girl's experience saved about 100 tourist lives at one of Phuket's beach resorts, Thailand. Tilly Smith informed the tourists about the possibility of a tsunami that would occur because she saw signs of a tsunami, which she had observed in geography lessons (Rao, 2007).

Teachers and school principals receive education and training to apply disaster education and skills. Knowledge about disasters can be given intensively by the teacher; therefore, a teacher must also know about disasters to become a disaster management command during the teaching and learning process to save their students and themselves. Teachers should have perspectives or viewpoints in providing understanding to the participants because the teacher plays a role in the disaster and plays a role in the pre-disaster so that students can have a disaster-aware character (Honesti and Djali, 2012). The perspective of disaster is a view that arises from personal experience or not, about what is a disaster and how to be a disaster alert. The research conducted by Lei (2014), aimed at identifying the teacher's perspective on their experience in disaster response and the management of the post-earthquake school in Sichuan 2008, the results of the study demonstrated that the experience of teachers and the environment had a significant impact in addressing disaster situations. According to (Lei, 2014) teachers are expected to play an active role in providing essential services to students, although they also face the same pressure in post-plan situations. Based on the study results, Barus \& Aminah (2021) states a significant increase in disaster knowledge after interventions were given to parents and teachers and the need to integrate disaster management programs into the curriculum considering Indonesia's geographical situation.

Based on the research conducted by Baker, Koray, and Elanur (2015), stating the perspective of the teacher who is very important from every purpose of disaster education is that students can know the safe position at the time of the earthquake occurs, students can apply for a secure job during the quake and can find out the place that became a hazard factor occupied if the earthquake occurred. In the effort to reduce disaster risk, the perspective of disaster requires a commitment to be integrated to the participants in the students; based on this, researchers feel it very important to conduct a study to be able to know the perspective of high school teachers in Aceh province about natural disasters. 
ge Ografi

\section{RESEARCH METHODS}

The research used descriptive statistics to explain, describe, and interpret teacher knowledge perspectives and natural disaster mitigation interactively and flexibly. Descriptive statistics cannot provide conclusions about the relationship between the teacher's knowledge perspective and natural disaster mitigation; therefore, linear regression analysis is carried out. Regression analysis will explain the relationship between the teacher's knowledge perspective on natural disaster mitigation and how much influence the teacher's knowledge perspective has on natural disaster mitigation.

The data used in this research is the primary data derived from the questionnaire results that shared with 389 high school teachers in Aceh province. Variables in this study are the perspective of teacher knowledge on natural disasters and the mitigation of natural disasters. There are 14 indicators/statements in each of the variables as measurements of the extent of the knowledge level of natural disasters and natural disaster mitigation. The response measurement of the respondent (Teacher) uses the summated rating technique, with scores of 1 to 4 . Namely as follows: Very know, not know, Know, and very knowledgeable. Measuring teacher knowledge of natural disasters is divided into four categories:

1. General knowledge

X1 : Natural disasters are many natural events that cause casualties and loss of matter and cannot be addressed by the public.

X14 : Disaster is not just God's destiny, but the natural process learned with science.

2. Causes of natural disasters

$\mathrm{X} 2$ : Earthquakes can cause other natural disasters.

X3 : Flood and landslide can cause other natural disasters.

X4 : Wind nipple can cause other natural disasters.
Available at http://jurnal.unimed.ac.id/2012/index.php/geo e-ISSN: 2549-7057 | p-ISSN: 2085-8167

X5 : Plate movements and volcano eruptions can be predicted by experts.

X6 : Forest fires can trigger other natural disasters.

X11 : Process of liquidation at seafloor can cause a Tsunami.

X12: Dryness can cause other disasters.

X13 : Full Moon can be used as a trigger for tidal waves or storms.

3. Natural disasters Classification

X7 : According to the cause, natural disasters are divided into three groups, namely climatological disasters, geological disasters, and extraterrestrial disasters.

4. Signs of natural disasters

X8 : Animal behaviour can be used as an Initial indicator in predicting natural disasters.

X9 : air temperature can be used as an indicator in the prediction of natural disasters.

X10 : The form of cloud can be used as an indicator in predicting natural disasters.

Teacher perspective measurement in natural disaster mitigation is divided into four categories:

1. Policy

Y1 : Local Wisdom is one of the community's efforts to reduce disaster risk.

Y2 : Every component in the school should be actively involved in maintaining mitigation tools to reduce disaster risk in the surrounding environment.

Y4 : Place students with special needs in the most accessible access to the exit

Y7 : During the disaster, people, only use clean water for essential purposes and MCK.

Y11: Ensure that natural disasters can avoid the structure and layout of school buildings. 
2. Standard operational procedures

Y3 : at the time of learning to teach in the classroom, there is a natural disaster that teachers will save themselves.

Y5 : reposition and bind the closet and make sure the exit is open towards the outside.

Y9 : Creating standard operational procedures in schools that are easy to understand and attended by school residents.

3. Planning

Y6 : Put the glass of the film in the glass window and put the class objects or ornaments in the closet.

Y7 : During the disaster, people, only use clean water for essential purposes and MCK.

Y8 : does not dispose of waste and other materials to maintain the surrounding environment.

Y9 : Creating standard operational procedures in schools that are easy to understand and attended by school residents.

4. Evacuation route, risk map, disaster

friendly school facilities.

Y12: Evaluation and renovation of the school building structure that is prone to damage from natural disasters.

Y13: Need to be determined safe gathering point for evacuation/evacuation purposes also known by parents/guardians.

Y14: The presence of disaster risk maps can help all elements in the school in the evacuation process.

According to the data characteristics, processing data into information is easy to understand and beneficial for solving problems in this research, conducted with descriptive analysis and simple linear regression analysis. Descriptive analysis relates only to describing or giving information about a data or situation or phenomenon, in other words, only to see the general picture of the data obtained without the conclusion of a relationship/event. So simple linear regression analysis was conducted to determine how much the influence of a teacher's perspective variable relationship about natural disaster (X) knowledge was against the dependent variables of natural disaster mitigation $(Y)$. Models of regression equations can be written as follows:

$$
y=\beta_{0}+x_{1}+\varepsilon \quad \text { Equation (1) }
$$

description:

y : Variable observation valuedependent

$\beta_{0}$ : The value of intercept regression model

x : Variable observation value Independent

$\varepsilon \quad:$ Residual on observation

The coefficient of determination or commonly denoted by $\mathrm{R}^{2}$, is one of the most straightforward and most widely used measures to test the quality of an equation of a regression line (Gujarati, 2004). The value of the coefficient of determination provides an overview of the suitability of independent variables in predicting dependent variables.

\section{RESULTS AND DISCUSSION}

The characteristic data of this research is the result of the response from respondents as many as 389 teachers, male gender 180 and 209 women. By age, the distribution of respondents by age, teachers, aged 20-30 years amounted to 89 teachers or $22.9 \%$. The most dominating period in this study was the teacher aged between 31-40 years old, with 204 teachers or $52.4 \%$. At the same time, the fewest are teachers over 50 years old, ranging from $27.2 \%$ only with 28 teachers. For more details, respondent data can be seen in Figure 1 below. 


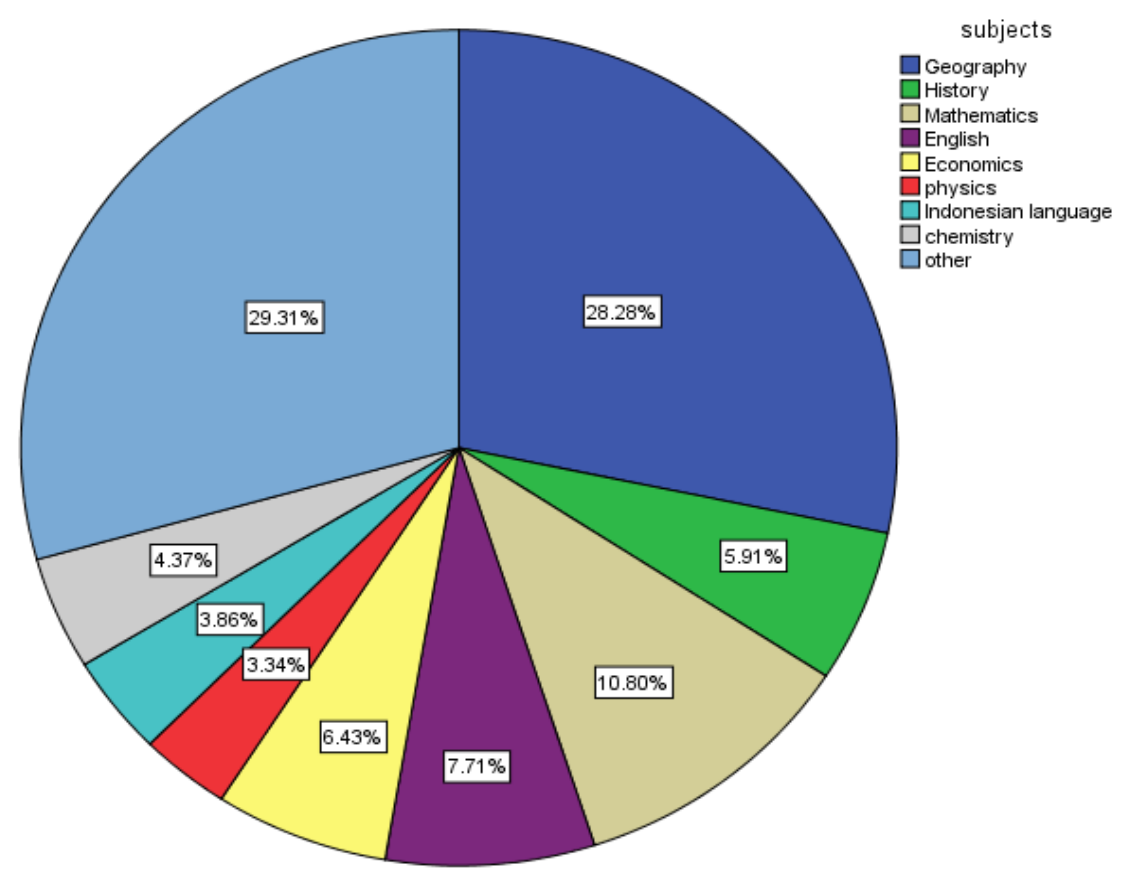

Figure 1. The Circle Diagram of the subject

Figure 1 shows the data classification of respondents (teachers) according to subjects that can consist of 9 categories, with the following characteristics of 389 teachers, $28.3 \%$ (110) Teachers are subject to geography, $10.8 \%$ (42) Teachers can have mathematics, $7.7 \%$ (30) teachers can learn the English language, $6.4 \%$ for economic study, $5.91 \%$ (23) teachers can learn historical subjects, $4.4 \%$ of teachers are subject to chemical subjects, $3.9 \%$ teachers are teaching
Indonesia language, 3.3\% teachers can learn physics and for other categories of $29.31 \%$ teachers who belong to different types of lessons. The types of tasks categorized into other categories are (Islamic religion, PKN, cultural arts, counselling, history, and Penjaskes). For more details, the description of the variable knowledge of natural disasters by category of knowledge can be seen in Table 1 below

Table 1. Description of natural disaster knowledge variables based on knowledge category.

\begin{tabular}{|c|c|c|c|c|}
\hline No & Knowledge category & Indicator & Mean & $\begin{array}{c}\text { Category } \\
\text { Assessment }\end{array}$ \\
\hline \multirow{2}{*}{1.} & \multirow{2}{*}{ General knowledge } & X.1 & 3.22 & \multirow{2}{*}{$\begin{array}{c}3.33 \\
\text { (High) }\end{array}$} \\
\hline & & X.14 & 3.44 & \\
\hline \multirow{5}{*}{2.} & \multirow{8}{*}{ Causes of natural disasters } & X.2 & 3.05 & \multirow{8}{*}{$\begin{array}{c}3.52 \\
\text { (Very high) }\end{array}$} \\
\hline & & X.3 & 2.94 & \\
\hline & & $\mathrm{X} .4$ & 3.2 & \\
\hline & & X.5 & 3.31 & \\
\hline & & X.6 & 3.16 & \\
\hline & & X.11 & 2.93 & \\
\hline & & X.12 & 3.06 & \\
\hline & & X. 13 & 2.99 & \\
\hline 3. & Classification of natural disasters & X.7 & 3.21 & $\begin{array}{c}3.21 \\
\text { (High) }\end{array}$ \\
\hline \multirow{3}{*}{4.} & \multirow{3}{*}{ Signs of natural disasters } & X.8 & 3.09 & \multirow{3}{*}{$\begin{array}{c}2.97 \\
\text { (High) }\end{array}$} \\
\hline & & X.9 & 3.05 & \\
\hline & & X.10 & 2.77 & \\
\hline
\end{tabular}

Source: Data Processing, 2020 
Based on table 1. The teacher's perspective in explaining the general knowledge of high-category disasters means that having a good view can bring out the proper action in the face of a disaster. In the results of this study, teachers are very aware of the causes of natural disasters so that they can improve their preparedness for natural disasters. Understanding the signs of natural disasters has an average of 2.97 high category but understanding this is low compared with other, knowledge.

Of the 14 indicators above, the two very high category indicators. This means the teacher's perspective will be two very high indicators value/ teachers are very aware of it. The teacher's view is very high in the category of disaster knowledge is not just the destiny of God but the process of nature that can be learned with science as many as 193 teachers from 389 teachers know about it. Out of the 14 indicators above, 12 indicators produce a high-category teacher perspective. A teacher's perspective on flooding and landslide can cause other natural disasters to be declared high category with details of 216 teachers knowing this very well of this amounting to 80 teachers. And 82 teachers stated not to know while the 11 teachers said firmly not knowing this. For more details, can be seen in Figure 2 below.
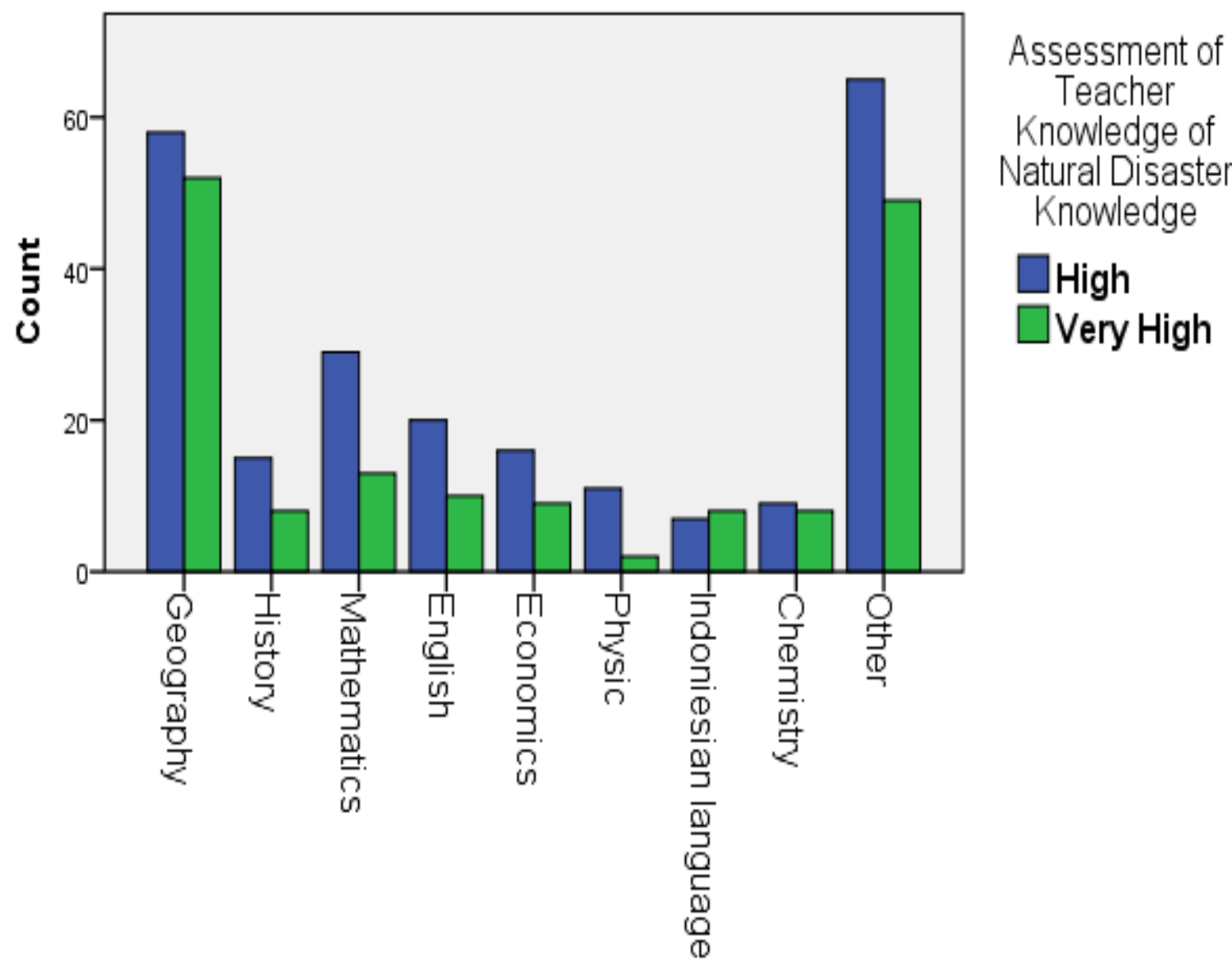

Figure 2. Distribution of teacher knowledge of natural disasters based on the subject.

These results by (Sumaatmadja 1997) explained that learning geography plays a vital role in seeking disaster. Geography studies study areas on the surface of the scattered Earth from specific geographical environments that demonstrate the regional system. Figure 2 explains that the average teacher's knowledge of natural disasters is based on a very high-level lesson on teachers who have geography studies. Teachers who have learned more about geography lessons are about the understanding of natural 
disasters. For more details, the description of the mitigation variables based on the category of natural disaster mitigation can be seen in Table 2 below.

Table 2. Description of the mitigation variables based on natural disaster mitigation categories.

\begin{tabular}{|c|c|c|c|c|}
\hline No & Knowledge category & Indicator & Mean & $\begin{array}{c}\text { Category } \\
\text { Assessment }\end{array}$ \\
\hline \multirow{5}{*}{1.} & & Y.1 & 3.34 & \multirow{5}{*}{$\begin{array}{c}3.16 \\
\text { (High) }\end{array}$} \\
\hline & & Y.2 & 2.22 & \\
\hline & Policy & Y.4 & 3.25 & \\
\hline & & Y.7 & 3.61 & \\
\hline & & Y.11 & 3.39 & \\
\hline \multirow{3}{*}{2.} & Operational standards Disaster & Y.3 & 3.17 & \multirow{3}{*}{$\begin{array}{c}2.96 \\
\text { (High) }\end{array}$} \\
\hline & procedure & Y.5 & 2.51 & \\
\hline & & Y.9 & 3.21 & \\
\hline \multirow{5}{*}{3.} & & Y.6 & 2.97 & \multirow{5}{*}{$\begin{array}{c}3.36 \\
\text { (Very high) }\end{array}$} \\
\hline & & Y.7 & 3.61 & \\
\hline & Planning & Y.8 & 3.60 & \\
\hline & & Y.9 & 3.21 & \\
\hline & & Y.10 & 3.40 & \\
\hline \multirow{3}{*}{4.} & Evacuation routes, risk maps, & Y.12 & 3.40 & \multirow{3}{*}{$\begin{array}{c}3.45 \\
\text { (Very high) }\end{array}$} \\
\hline & disaster-friendly school & Y.13 & 3.50 & \\
\hline & facilities & Y.14 & 3.44 & \\
\hline
\end{tabular}

Source: Data Processing, 2020

Based on table 2, very high category mitigation is on planning and preparedness of evacuation routes, risk maps, disasterfriendly school facilities, regarding policy and operational standards of disaster procedures.

The results obtained are from 14 indicators, 1 Low-category indicator, two high-category indicators. And 11 very high category indicators. The teacher's perspective in mitigating low-category natural disasters is seen in the statement that if every component in the school is actively involved, it can maintain mitigation and impact disaster risk reduction in the surrounding environment. A total of 160 teachers stated not to know it, strongly unaware of 98 teachers and the number of teachers who knew this as many as 80 teachers.

A total of 154 teachers stated that knowing it would save oneself in a natural disaster during the teaching and learning process. This means the teacher is very aware that it will be done either spontaneously or not. The perspective on this indicator is high category, where 40 teachers do not know about the action. The mitigation indicators by placing the students with special needs in the most accessible access to the exit expressed a high perspective. Where 208 teachers knew this effort and only five teachers from 389 teachers were very unaware. High category mitigation perspectives on installing film Glass in glass windows and placing class objects or ornaments on cabinets, known by as many as 203 teachers. As many as 68 teachers stated not to know it. The teacher's perspective is very high on efforts to not dispose of waste, waste, and other materials to maintain the environment as many as 242 teachers are very aware of it. And only two teachers did not know it. For more details on the distribution of teacher knowledge about natural disaster mitigation based on subjects can be seen in Figure 3 below. 


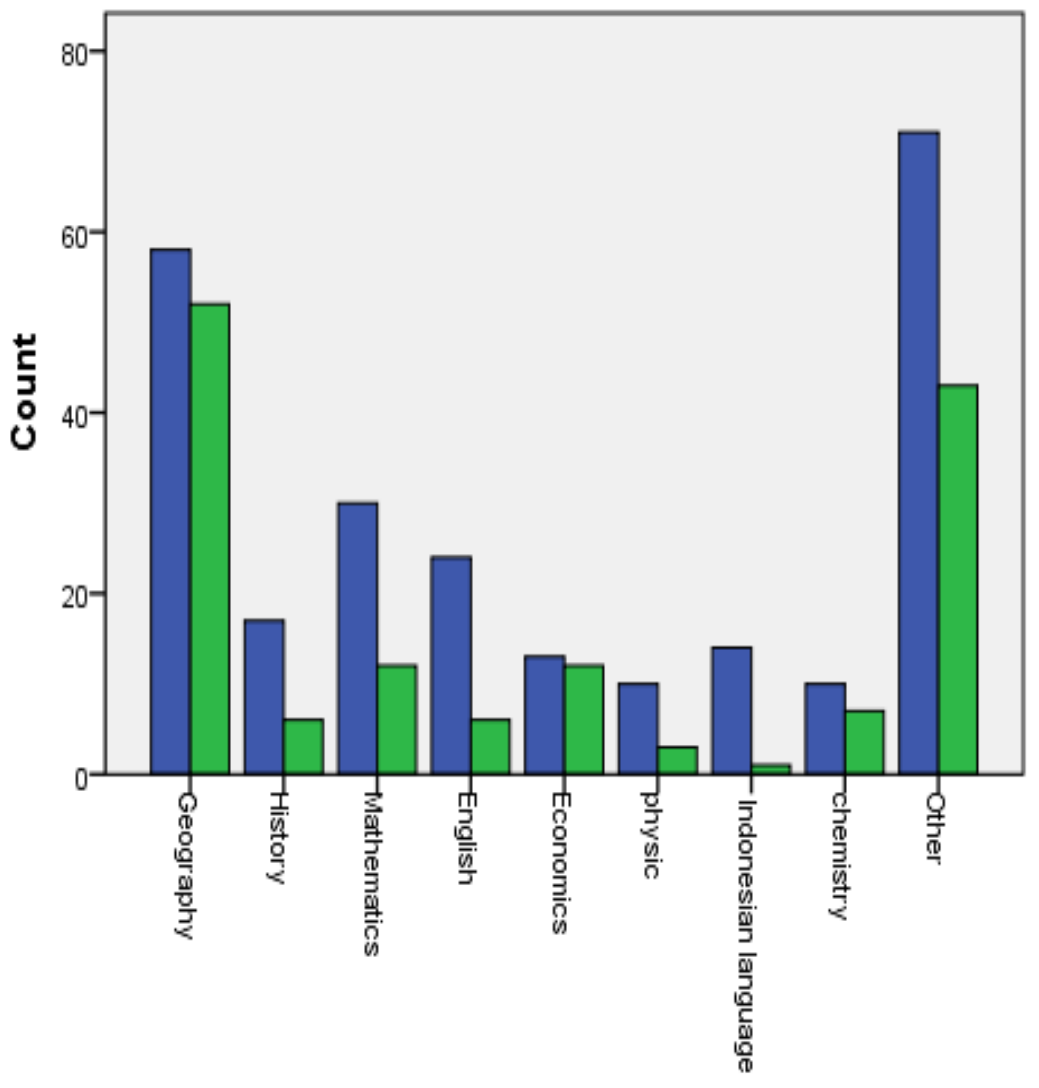

Teacher Knowledge

Assessment on

Natural Disaster

Mitigation

$\square$ High

$\square$ Very High

Figure 3. Distribution of teacher knowledge to natural disaster mitigation based on the subjects.

Based on Figure 3, I explained that the average teacher's knowledge of natural disaster mitigation is based on excellent lessons from teachers who have a class on geography. A teacher's perspective for geography lessons can affect better disaster actions or comfort.

Based on the teacher's perspective on disaster knowledge and disaster mitigation, it clear that educators have unknown knowledge and efforts. According to Nurdin (2019), some high school teachers in Banda Aceh tried to learn about individual disasters, associating with lessons taught to learners. However, this depends on the teacher's awareness in person, and only a tiny part does this, given the high demands of each subject. Another obstacle is limited regular training for teachers, especially in the integration of disaster material, the absence of special funds allocation in school, the weight of the teacher's workload due to the frequent turnover of the curriculum causes the process of integrating knowledge of this disaster becomes often neglected by the school (Nurdin, 2019).

The hypothesis analysis in this study used the simple linear regression method to see the relationship between the teacher's perspective on the knowledge of natural disasters on natural disaster mitigation. It also has a model that will explain the changes posed by the teacher's perspective on natural disaster mitigation-testing the assumptions that must be done before modelling the relationship between teacher knowledge on disaster mitigation, namely normality, linearity, homogenity and autocorrelation.

Normality test aims to test whether, in the regression model, the residual variable has a normal distribution or not (Ghozali, 2011). The residual normality assumption is fulfilled if the data points on the standard plot of unstandardized residuals follow a straight line. For more details can be seen in Figure 4 below. 


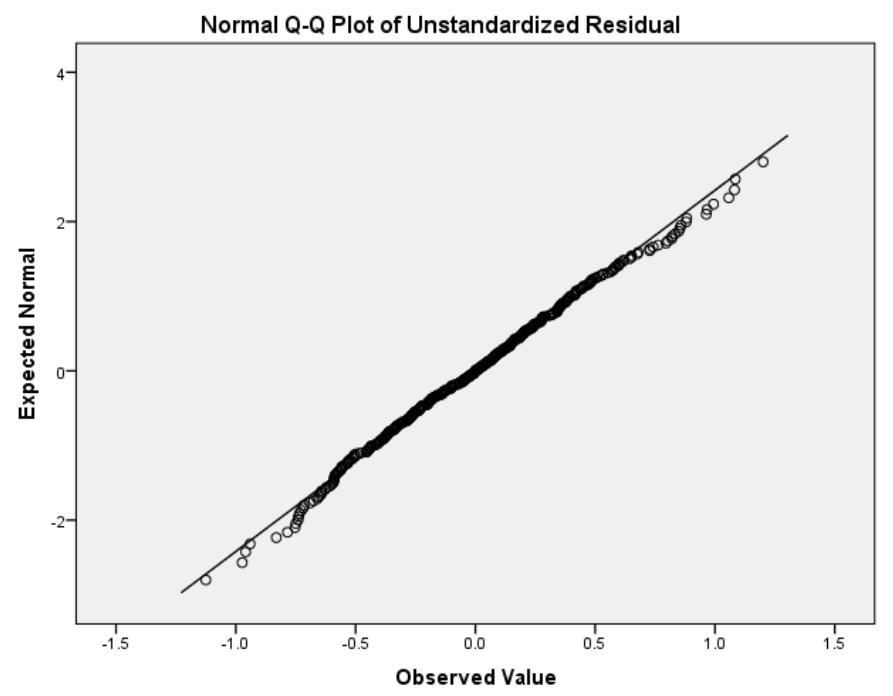

Figure 4 . The plot of the distribution of the residual values.

Based on the Plot and Kolmogorov Smirnov Value, normally distributed data is assumed to be fulfilled, which means that the average error error is equal to zero. The regression model is correct because it is free of errors. And the prediction model becomes appropriate. The regression analysis model is linear. It means that any change in the variable of the teacher's perspective on natural disasters must be proportionally followed by a difference in the variable of the teacher's perspective on natural disaster mitigation. For more details can be seen in Figure 5 below.

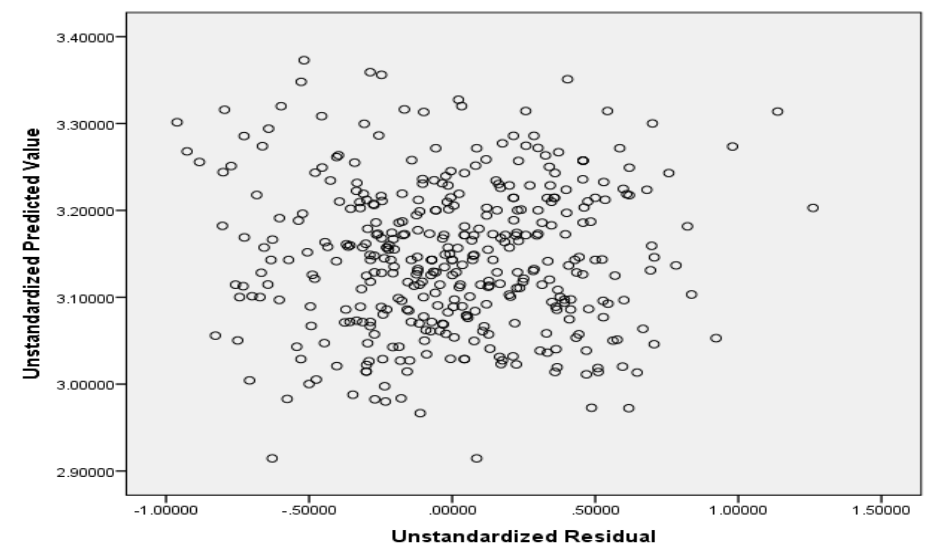

Figure 5. Scatter Plot of the unstandardized residual values.

Through the scatterplot, the relationship between the perspective of teacher knowledge about natural disasters and the view of teachers on natural disaster mitigation follows a linear model.

The error variance (residual) generated in the regression model is constant, meaning that there is no heterogeneity. The results of testing the autocorrelation assumption using the Durbin Watson value, the calculated Durbin Watson value obtained will be compared with the Durbin Watson (DW) Table value, DU (Durbin Upper) value and DL (Durbin Lower) value. If DW > DU, then there is no positive autocorrelation. With regard sig $0.05 \mathrm{k}=1$ (independent variable) and $\mathrm{n}=$ 389 , it is obtained $\mathrm{DL}=1.874$. 
$\mathrm{DL}<\mathrm{DW}>4$-DW

$1,874<2.124>4-2.124$

$1,874<2.214>1.786$

Testing the assumptions has been fulfilled, then simple linear regression modelling will be carried out to see the relationship between the teacher's perspective on natural disaster knowledge and natural disaster mitigation. The regression equation obtained is as follows:

$$
\begin{gathered}
\mathrm{Y}_{\text {(Natural disasters Mitigation) }}=2.515+0.200 \mathrm{X} \\
\text { (Natural Disaster Knowledge })+\varepsilon
\end{gathered}
$$

If another variable is constant, the meaning of the equation is consistent, then the average teacher's perspective in the mitigation of natural disasters will change by itself by 2,515. Factors of biological knowledge provide a positive relationship, which means that the average teacher's perspective in natural disaster mitigation will increase by 0200 each additional teacher's understanding of natural disasters.

The T-Test is conducted to analyze the significance of natural disaster knowledge on natural disaster mitigation. With the hypothesis as follows:

$\mathrm{H}_{0}$ : No significant influence between Natural knowledge disasters with natural disaster mitigation.

$\mathrm{H}_{1}$ : There is a significant influence between disaster knowledge Natural disaster mitigation.

Table 3. T-test Result

\begin{tabular}{l|c|c}
\hline \multicolumn{1}{c|}{ Variable } & T value & Sig Value \\
\hline Constant & 17.186 & 0.000 \\
$\begin{array}{l}\text { Natural Disaster } \\
\text { Knowledge }\end{array}$ & 4.347 & 0.000 \\
\hline
\end{tabular}

Source: Processed Data by SPSS, 2020.

In table 3 , it canseen that if a reviewer is from a sig value of $<0.05$, then $\mathrm{H}_{1}$ is accepted. The same decision can also be seen in the value score $(4.347)>$ table (1.966). In conclusion, there is a significant influence on the knowledge of natural disasters with the mitigation of natural disasters.
The coefficient of determination is used to know how much a relationship is from a teacher's perspective on natural disaster mitigation of natural disasters. The coefficient of determination will explain how changes or variations in other variables can explain many modifications or variations of a variable.

Table 4. Value of coefficient of determination

\begin{tabular}{c|c}
\hline $\mathbf{R}^{2}$ value & adj $\mathbf{R}^{2}$ value \\
\hline 0.047 & 0.044 \\
\hline
\end{tabular}

Source: Processed Data by SPSS, 2020.

$\mathrm{R}^{2}$ values in table 4 . is $0.047=47 \%$, which means teacher perspective variables can explain natural disaster mitigation variables in natural disaster knowledge by $47 \%$. The remaining amount (53\%) Other variables that are not researched.

\section{CONCLUSION}

Based on the results of analysis and discussion that has been outlined, it can be presented a few conclusions from the analysis results are as follows:

1. The perspective of high school teachers in Aceh Province in terms of natural disasters is adequate; this is demonstrated from the average results obtained in the high category. The average teacher knows the causes of disasters, the classification of natural disasters, and signs of natural disasters.

2. The perspective of high school teachers in Aceh Province in terms of natural disaster mitigation is very high; it is shown from the average results obtained very high category. The average teacher knows the policy, SOP, or planning to mitigate natural disasters.

3. The relationship between teachers perspectives in natural disaster knowledge will positively affect the mitigation of natural disasters. The understanding of natural disasters has a significant influence on the change in natural disaster mitigation. 


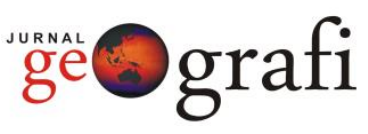

\section{REFERENCE LIST}

Adiyoso, W., \& Kanegae, H. (2013). Effectiveness of disaster-based school program on students' earthquakepreparedness. Journal of Disaster Research, 8(5), 1009-1017.

Adiyoso, W., \& Kanegae, H. (2013). The preliminary study of the role of Islamic teaching in the disaster risk reduction (a qualitative case study of Banda Aceh, Indonesia). Procedia Environmental Sciences, 17, 918-927.

Alisic, E. (2012). Teachers' perspectives on providing support to children after trauma: A qualitative study. School psychology quarterly, 27(1), 51.

Arif, M., \& Rosni, R. (2011). Manajemen Bencana Alam Hubungan dengan Kepuasan Publik di Daerah Bencana (Studi Didaerah Bencana di Kabupaten Mandailing Natal Provinsi Sumatera Utara). Jurnal Geografi, 3(2), 94-106.

Barus, S., \& Aminah, S. (2021). Penerapan Pola Simulasi Mitigasi Bencana Alam (Gempa Bumi) Pada Guru dan Orang Tua Siswa Di Sekolah Luar Biasa. Jurnal Keperawatan BSI, 9(1), 41-48.

Bungin, B. (2007). Penelitian kuantitatifkomunikasi, Ekinomi dan Kebijakan Publik serta Ilmu Sosial lainnya. Edisi Satu. Jakarta. Prenada Media Grup.

Cvetković, V., Dragičević, S., Petrović, M., Mijalković, S., Jakovljević, V., \& Gačić, J. (2015). Knowledge and perception of secondary school students in Belgrade about earthquakes as natural disasters. Polish journal of environmental studies, 24(4), 1553-1561.

Damanik, M. R. S., \& Restu, R. (2012). Pemetaan Tingkat Risiko Banjir dan Longsor Sumatera Utara Berbasis Sistem Informasi

Geografis. Jurnal Geografi, 4(1), 29-42.

Djali, N. (2013). Pendidikan Kebencanaan Di Sekolah-Sekolah Di Indonesia Berdasarkan Beberapa Sudut Pandang Disiplin Ilmu Pengetahuan. Jurnal Momentum ISSN 1693-752X, 12(1).

Erdur-Baker, Ö., Kasapoğlu, K., \& Yılmaz, E. (2015). The objectives of disaster education
Available at http://jurnal.unimed.ac.id/2012/index.php/geo e-ISSN: 2549-7057 | p-ISSN: 2085-8167

from teachers' perspectives. Journal of Human Sciences, 12(1), 975-990.

Gujarati, D. N., Bernier, B., \& Bernier, B. (2004). Econométrie (pp. 17-5). Brussels: De Boeck.

Karanth, R. V. (2007). Imperatives for tsunami education. Current Science, 93(1), 8.

Karnawati, D., \& Pramumijoyo, S. (2008). Strategy for promoting education for natural disaster reduction in Indonesia and ASEAN region. In B. Rouhban, \& $R$. Shaw, The first world landslide forum (pp. 1-4).

Lei, B. Y. (2014). Teachers' perceptions and perspectives of school disaster management over the medium term following the 2008 earthquake in Sichuan province China (Doctoral dissertation, University of Leicester).

Lekalakala, M. J. (2011). Teacher perceptions about lesson planning to include a disaster risk reduction focus. Master's thesis, Disaster Management Training and Education Centre for Africa, University of the Free State, South Africa, 156.

LIPI \& UNESCO. (2010). Cerita dari Aceh: membangun kapasitas dan sekolah siaga bencana. Jakarta: LIPI \& UNESCO.

Nakano, G., Ramírez-Herrera, M. T., \& Corona, N. (2019). Effects of decontextualized tsunami disaster education: A case study of schools in Acapulco, Mexico. Journal of Natural Disaster Science, 39(2), 19-33.

Nurdin, N. (2019). Disaster risk reduction in education and the secondary high school science curriculum in Indonesia (Doctoral dissertation, UCL (University College London).

Nurmayani, H. (2018). Pengaruh Organizational Silence (OS) Terhadap Organizational Citizenship Behavior (OCB) dan Dampaknya Terhadap Kinerja Badan Penanggulangan Bencana Aceh. ETD Unsyiah.

Oxfam, A. A. (2012). Analisis Kerentanan dan Kapasitas Partisipatif. Jakarta: Oxfam.

Rao, A. V., \& Rao, L. G. (2007). Carotenoids and human health. Pharmacological research, 55(3), 207-216. 
RI (Republik Indonesia). (2007). UndangUndang No. 24 Tahun 2007 tentang Penanggulangan Bencana. Jakarta: Badan Nasional Penanggulangan Bencana.

Sari, S. A. (2019). Integrasi Kurikulum Kebencanaan dan Perangkat Pembelajaran dalam Meningkatkan Kompetensi Kesiapsiagaan. In TALENTA Conference Series (Vol. 2, No. 2, pp. 361-369). Universitas Sumatera Utara Selection and peer-review under responsibility of Konferensi Nasional Sosiologi VIII 2019.

Siregar, N. (2017). Implementasi Making Aceh Safer Trough Disaster Risk Reduction in

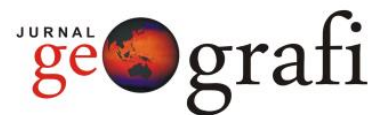

Development (DRR-A) Project Oleh United Nations Development Programme (UNDP) Dalam Upaya Mengurangi Resiko Bencana di Aceh 2009-2012. Banda Aceh. eJournal Ilmu Hubungan Internasional, 5(3), 775-788.

Sumaatmadja, N. (1997). Metodologi pengajaran geografi. Jakarta: Bumi Aksara.

Wedyawati, N., Lisa, Y., \& Selimayati, S. (2017). Pengaruh Model Pembelajaran IPA Terintegrasi Mitigasi Bencana Terhadap Hasil Belajar. Edukasi: Jurnal Pendidikan, 15(2), 261-273. 